Volume 3 No. 1 Bulan Juni Tahun 2021

E-ISSN: 2761-2982 | P-ISSN: 2716-2893

https://journal.upnvj.ac.id/index.php/esensihukum/index

\title{
PROYEKSI EKONOMI BEBERLANJUTAN DALAM UU NOMOR 11 TAHUN 2020 DALAM PRESPEKTIF MASLAHAT SEBAGAI NILAI FUNDAMENTAL EKONOMI ISLAM
}

\author{
Ahmad Muhtar Syarofi ${ }^{1}$ \\ ${ }^{1}$ Fakultas Syariah, Hukum Ekonomi Syariah Institut Agama Islam Malang \\ Email: syarofi@alqolam.ac.id
}

\begin{abstract}
This research on Law No. 11 of 2020 concerning Environmental Cluster Job Creation in the Perspective of Islamic Sustainability Economic Benefits is a normative juridical research using a statutory approach and combines a comparative approach to Islamic law as a comparison and an instrument in determining research prescriptions. In this study, the author intends to conduct a critical study using the Islamic sustainability economic paradigm of Law No. 11 of 2020 on Environmental Cluster Job Creation with the aim of explaining the risk aspects for the environment and the perspective of benefit as a fundamental value of Islamic economics. In summary, the conclusion of this research is that starting from the spatial planning stage and the preparation of the AMDAL document, it tends to weaken the role of the community and reduce public information access rights related to the environment and the economy as well as in the view of maqashid sharia which in this case is an Islamic sustainable economic framework, the establishment of regulations in Law No. 11 of 2020 still needs improvement in many aspects. This is because several regulations for environmental protection and preservation as an instrument of hifdz bi'ah are still contrary to the five basic objectives of shari'ah that must be protected and cared for including: (1) Hifdz al-din, (2) Hifdz al-nafs, (3) Hifdz al-'aql, (4) Hifdz al-nasl, and (5) Hifdz al-mal. The pandemic condition that resulted in the weakening of the national economy became the government's pretext for making regulations aimed at accelerating investment. However, it should be noted that prioritizing the economy without paying attention to the environmental and social conditions of the community will certainly have a negative impact on environmental sustainability. The destruction of the environment as an essential supporter of human life will result in the threat of life/human existence itself.
\end{abstract}

Keywords: Projections, Sustainable Economy, Law Number 11 of 2020, Fundamentals, Islamic Economics.

\begin{abstract}
Abstrak
Penelitian tentang UU No.11 Tahun 2020 tentang Cipta Lapangan Kerja Cluster Lingkungan Hidup Dalam Prespektif Maslahat Ekonomi Keberlanjutan Islam ini merupakan penelitian yuridis normatif dengan menggunakan pendekatan Undang-Undang (statue Approach) Dan mengkombinasikan pendekatan perbandingan hukum islam sebagai pembanding dan instrumen dalam menentukan preskripsi penelitian. Dalam penelitian ini penulis bermaksud melakukan telaah kritis menggunakan paradigma ekonomi keberlanjutan islam terhadap UU No.11 tahun 2020 Cipta Kerja Klaster Lingkungan Hidup dengan tujuan menjelaskan aspek resiko bagi lingkungan dan Prespektif Maslahat Sebagai Nilai Fundamental Ekonomi Islam. Secara ringkas Kesimpulan
\end{abstract}


Hasil Penelitian ini ialah di mulai sari tahap perencanaan tata ruang dan penyusunan dokumen AMDAL cenderung melemahkan peran masyarakat serta pengurangan hak akses informasi masyarakat terkait lingkungan dan ekonomi serta dalam pandangan maqashid syariah yang dalam hal ini merupakan framework ekonomi berkelanjutan islam, penetapan regulasi dalam UU No 11 tahun 2020 masih membutuhkan perbaikan dalam banyak sisi. Hal itu dikarenan dari beberapa regulasi perlindungan dan pelestarian lingkungan sebagai instrumen hifdz bi'ah masih bertentangan dengan lima dasar tujuan syari'ah yang harus dilindungi dan di rawat diantaranya: (1) Hifdz al-din, (2) Hifdz al-nafs, (3) Hifdz al-'aql, (4) Hifdz al-nasl, dan (5) Hifdz al-mal. Kondisi pandemi yang mengakibatkan lemahnya perekonomian nasional menjadi dalih pemerintah untuk membuat regulasi yang bertujuan untuk mepercepat investasi. Namun patut menjadi catatan memprioritaskan ekonomi tanpa memperhatikan kondisi lingkungan dan sosial masyarakat tentu akan memberikan dampak negatif bagi keberlanjutan lingkungan hidup. Rusaknya lingkungan hidup sebagai pendukung esensial kehidupan manusia akan berakibat terancamnya kehidupan/eksistensi manusia itu sendiri.

Kata Kunci: Proyeksi, Ekonomi Beberlanjutan, UU Nomor 11 Tahun 2020, Fundamental, Ekonomi Islam.

\section{Pendahuluan}

\subsection{Latar Belakang}

Dewasa ini, semakin banyak orang sadar bahwa sistem daya dukung lingkungan yang terus merosot tajam tengah menuntun kita kepada kerusakan dan bencana berkepanjangan. Pada dasarnya degradasi lingkungan telah terjadi dibeberapa peradaban tempo dulu, tercatat beberapa peradaban seperti mestopomia dan peradaban maya diyakini hancur karena faktor ekologi. Namun yang membedakan peradaban hari ini dengan peradaban sebelumnya adalah hari ini kita dihadapkan dengan permasalahan ledakan penduduk, teknologi yang mampu menciptakan penghancuran secara luas, dan sistem ekonomi yang tak kenal batas. Kerusakan yang ditimbulkan oleh peradaban kali ini tidak hanya menghancurkan lingkungan secara regional seperti peradaban-peradaban sebelumnya. Namun pengaruh kerusakan alam menyebar dalam skala planet yang tentu dapat berakibat pada spesies penghuni planet ini termasuk spesies kita sendiri.

Masalah lingkungan hidup pada dasarnya tidak bisa kita simpulkan secara dini sebagai persoalan tunggal. Persoalan tersebut adalah serangkaian persoalan yang saling berkaitan satu sama lain. Dalam ilmu yang mempelajari sistem bumi ada konsep yang dikembangkan oleh para ilmuan yang hari ini terkenal sebagai "batas-batas planet". Dimana ada sembilan ambang batas maksimal yang telah ditetapkan atau dipertimbangkan sebagai indikator maksimal metabolismeplanet ini untuk berjalan memperbaiki dirinya sendiri. Hal tersebut terkait dengan: (1) perubahan iklim; (2) keasaman air laut; (3) penipisan lapisan ozon; (4) batas aliran geokimia;

(5) pemanfaatan air bersih; (6) pemanfaatan lahan; (7) hilangnya keanekaragaman hayati; (8) pelepasan aerosol ke atmosfer; (9) dan yang terahir adalah polusi kimia. Dimana dari kesembilan kategori tersebut setidaknya ada tiga kategori yang telah melewati ambang batas atasnya yakni perubahan iklim ekstrem, keaneka ragaman hayati dan campurtangan manusia 
terhadap gas nitrogen. ${ }^{1}$

Dalam kaitanya dengan ambang batas perubahan iklim menduduki peringkat teratas dalam persoalan lingkungan. Tercatat pada tahun 2010 sampai tahun 2015 merupakan tahun terpanas sejak 131 tahun sejak diperkenalkan alat pengukur suhu global ${ }^{2}$ yang mana hal tersebut berakibat pada lelehnya es di samudra artik, kenaikan permukaan air laut, pencairan cepat beberapa gletser sebagai sumber mata air, kekeringan mencekam³, dan suhu yang lebih panas sehingga menyebabkan kegagalan panen dan punahnya spesies akibat perubahan iklim yang ekstrem.

Pada tingkat keasaman air laut pun demikian, pada masa pra industri keasaman air laut terdapat pada angka 3,44 sementara ambang batasnya adalah 2,75 dimana lebih rendah dari ini adalah kematian bagi masif bagi seluruh spesies bercangkang dan sementara ini nilainya adalah 2,294. Selain itu semua indikator-indikator yang lain yang menjadi ambang batas ketahanan sistem planet ini juga hampir mendekati batasanya. Tentu ini adalah ancaman yang serius dimana lingkungan adalah tempat bergantungnya seluru kehidupan spesies termasuk manusia. Dimana kerusakan ekologis tersebut berkaitan erat dengan kegiatan manusia modern yang mengedepankan pertumbuhan ekonomi, efisiensi dan orientasi pada laba dalam sistem ekonominya. Untuk mendukung kebijakan tersebut, berbagai sumber daya alam yang ada dieksploitasi sedemikian rupa sehingga mampu mendukung proses industrialisasi sebagai motor penggerak utama ke arah terwujudnya masyarakat modern 5 .

Konsekuensi dari pilihan kebijakan ekonomi tersebut ialah kerusakan lingkungan dalam skala luas. Di indonesia, laju deforestasi selama kurun Orde Baru berkuasa makin meningkat pertahunya. FAO menyebutkan bahwa dalam rentan 1976-1980 angka deforestasi mencapai 550.00 hektar/tahun. Peningkatan ini terjadi pada tahun-tahun berikutnya yaitu menjadi 1 juta hektar/tahun pada tahun 1980; 1,2 juta hektar/tahun pada tahun 1985; hingga 1,7 hektar/tahun pada 1985-1997. Sementara itu pada era reformasi pembukaan wilayah hutan juga masih menunjukan angka yang tinggi dimana 3,52 juta hektar/tahun pada kurun 1997-2000; dan 1,09 juta hektar/tahun pada kurun 2014-2015. Yang demikian tentu akan menimbulkan dampak turunan seperti rusaknya biodiversitas alam, banjir, longsor hingga perubahan iklim. Kondisi ini menempatkan Indonesia sebagai penyumbang emisi gas karbon terbesar keenam di

19.

${ }^{1}$ Jhon Bellamy Foster et.al., (2010), The Ecological Rift, New York, Montly Review Press, hlm. 13-

2 U.S Departement Of Commerce National Data Center, (2010), Mstate climate global analysis annual, http://www.ndcd.noaa.gov/sotc/global/201013 (diakses pada 20 maret 2021).

${ }^{3}$ Fred magdof and Foster, (2011), Lingkungan hidup Dan Kapitalisme, Terjemahan oleh Pius Ginting, Cetakan I, Tanggerang Selatan, Marjin Kiri, hlm. 5.

${ }^{4}$ Rockström J, Steffen W, Noone K, Persson A, Chapin FS 3rd, Lambin EF, Lenton TM, Scheffer M, Folke C, Schellnhuber HJ, Nykvist B, de Wit CA, Hughes T, van der Leeuw S, Rodhe H, Sörlin S, Snyder PK, Costanza R, Svedin U, Falkenmark M, Karlberg L, Corell RW, Fabry VJ, Hansen J, Walker B, Liverman D, Richardson K, Crutzen P, Foley JA. A safe operating space for humanity. Nature. 2009 Sep 24;461(7263):472-5. doi: 10.1038/461472a. PMID: 19779433.

${ }^{5}$ Fakih, Mansour. (2006), Runtuhnya Teori Pembangunan dan Globalisasi. (Yogyakarta: Pustaka Pelajar dan Insist Press, hlm. 55. 
dunia ${ }^{6}$.

Hal diatas merupakan salah satu contoh pola pengelolaan aktivitas ekonomi yang menyebabkan kemrosotan lingkungan hidup pada skala yang luas. Sesungguhnya masih terdapat contoh lain yang dapat menunjukan kondisi yang sama terhadap kondisi tersebut. Sebagai contoh pengelolaan "energi kotor" batu bara yang menghasilkan polutan dan kerugian materiil terhadap warga sekitar, limbah pabrik, managermen sampah yang buruk serta berbgai kerugian lain harus didistribusikan ke masyarakat sekitar dan alam sebagai konsekuensi dari pengejaran pertumbuhan ekonomi. Konsidisi demikian pula yang dikemudian hari akan menghasilkan ancaman serius terhadap generasi sekarang dan juga yang akan datang.

Tertanggal 5 oktober 2020 undang-undang Cipta Kerja usulan telah resmi disahkan dalam rapat paripurna dewan perwakilan rakyat (DPR). UU ini merupakan agenda percepatan ekonomi yang digagas oleh pemerintahan presiden Joko Widodo. Menggunakan pendekatan Omnibus Law kurang lebih 80 UU dan 1.200 pasal bisa di revisi hanya dengan satu UU Cipta Kerja yang juga menyangkut lintas sektor. Menggunakan konsep Omnibus, undang-undang ini bertujuan untuk menyederhanakan, meregulasi ulang, dan merubah beberapa aturan lintas sektor terkait ekonomi yang dinilai tumpang tindih regulasi sehingga tak jarang menjadi muara konflik birokrasi. Selain itu, berbelit-belitnya aturan juga akan menghambat arus investasi yang akan masuk ke Indonesia sehingga dalam mengejar ketertinggalan pertumbuhan ekonomi indoesia tidaklah mempunyai daya saing yang mumpuni.

Sebagai contoh pemerintah mengatakan bahwa kewajiban seperti analisis mengenai dampak lingkungan (AMDAL) dan kewajiban Izin Mendirikan Bangunan (IMB) menyulitkan investor. Oleh sebab itu aturan-aturan ini harus disederhanakan. Oleh sebab itu konsep Omnibuslaw kiranya merupakan hal yang tepat sebab yang dititik beratkan adalah penyerdehanaan berbagai aturan dengan harapan menghilangkan tumpang tindih aturan sehingga memperbaiki iklim investasi, memperkecil kemungkinan konflik kebijakan serta mengefisiensi proses pembuatan perundang-undangan baik dari sisi administrasi maupun politik dalam pembahasan di parlemen ${ }^{7}$.

Dalam penyederhanakan aturan ini nampak menimbulkan permasalahan lain terutama berkaitan dengan lingkungan hidup. Dalam beberapa pasal ditemukan muatan kontroversial terutama perihal kelangsungan lingkungan hidup. Alih-alih menjamin kelangsungan pelestarian lingkungan hidup sebagai upaya mewujudkan ekonomi berkelanjutan, dengan dalih menggenjot investasi beberapa pasal tersebut justru mengabaikan aspek lingkungan. Salah satu contoh UU Cipta Kerja menghapus pasal 38 UU No. 39 Tahun 2009 tentang perlindungan dan pengelolaan lingkungan hidup, yang mana dalam pasal tersebut izin perusahaan yang melanggar ketentuan pengelolaan lingkungan dapat dicabut apabila

${ }^{6}$ Forest Watch Indonesia, (2018), Deforestasi Tanpa Henti: Potret Deforestasi di Sumatera Utara, Kalimantan Timur, dan Maluku Utara. Bogor, Forest Watch Indonesia, hlm. 6.

7 Antoni Putra," (2020), Penerapan Omnibus Law Dalam Upaya Reformasi Regulasi” Jurnal Legislasi Indonesia, vol.17, hlm. 2. 
ditemukan pelanggaran melalui keputusan pengadilan. Penghapusan pasal ini jelas berpotensi mereduksi peran masyarakat dalam pengawasan izin lingkungan hidup serta menutup akses terhadap proses peradilan (acces to justice).

Dari berbagai permasalahan diatas dapat kita simpulkan bahwa dalam ekonomi berkelanjutan dan berkeadilan yang memperhatikan lingkungan mutlak harus diperhatikan dalam rangka melindungi alam sebagai penopang kehidupan manusia. Termasuk dalam pembuatan Uundang-undang yang mana dalam pelaksanaanya tentu berkaitan erat dengan pola ekonomi yang akan jalankan.

Konsep pencegahan kerusakan lingkunan yang berkeadilan akibat pola ekonomi manusia yang eksploitatif pada dasarnya sudah dirumuskan oleh UNEP (United Nation Enivorment Programe) dengan ekonomi hijaunya. United Nations Environmental Program (UNEP) dalam dokumen berjudul "Towards A Green Economy" mendefinisikan green economy sebagai suatu sistem ekonomi yang dapat meningkatkan kualitas manusia dan keadilan sosial sekaligus juga dapat mereduksi risiko lingkungan dan kelangkaan ekologis (UNEP, 2011) $)^{8}$.

Yang membedakan konsep ekonomi ini dengan ekonomi sebelumnya adalah penilaian langsung nilai ekonomi dan penghitungan biaya yang sebelumnya tidak diperhatikan sebagai modal (konsep modal jujur) seperti polusi, kerusakan lingkungan dan sebagainya. Namun alihalih dapat mengurangi kerusakan lingkungan regulasi-regulasi berbasis pasar atas persoalan lingkungan dan keadilan ini hanya menjadikan perubahan diatas kertas, tidak dalam realitas ${ }^{9}$. Sebagai contoh perdagangan karbon yang menjadi salah satu program ungulan ekonomi hijau hari ini hanya memberikan landasan pada emisi yang sudah ada ${ }^{10}$.

Selain ekonomi alternatif berbasis pasar yang kurang efektif dalam menekan laju kerusakan alam serta ketimpangan ekonomi ekstrim, sebagai negara yang mayoritas beragama Islam ${ }^{11}$ tentu pandangan-pandangan islam tentang ekonomi yang berkelanjutan layak kita gunakan sebagai paradigma dasar dalam melihat berbagai persoalan yang berkaitan dengan ekonomi, tak terkecuali pembentukan undang-undang yang berkaitan erat dengan ekonomi. Islam sendiri mengenal konsep "falah" sebagai aspek fundamental ekonomi syariah. Dimana dalam konsep ini menurut Muhammad Muhyiddin Qaradaghi Al-falah dapat dimaknai kebahagiaan dan keberuntungan dunia dan akhirat yang dilihat secara komperhensif dari seluruh aspek kehidupan termasuk lingkungan hidup sebagai penompang hidup manusia ${ }^{12}$.

\footnotetext{
${ }^{8}$ Institut pertanian Bogor (t.t). Green Economy menuju ekonomi keberlanjutan. Bogor: IPBPerss

${ }^{9}$ Fred magdof and Foster, (2011), Lingkungan hidup Dan Kapitalisme, Terjemahan oleh Pius Ginting, Cetakan I, Tanggerang Selatan, Marjin Kiri, hlm. 12.

${ }^{10}$ Ibid hal 140

11 Viva Budy Kusnandar, Berapa Jumlah Penduduk Muslim Indonesia?, Katadata, https://databoks.katadata.co.id/datapublish/2019/09/24/berapa-jumlah-penduduk-muslim-indonesia (24 September 2019).

${ }^{12}$ Khaerul Aqbar, Azwar Iskandar, Akhmad Hanafi Dain Yunta, (2020), "Konsep Al-Falah Dalam Islam Dan Implementasinya Dalam Ekonomi”, Bustanul Fuqaha: Jurnal Bidang Hukum Islam Vol. 1, No. 3 hlm. 519.
} 
Dalam penelitian ini penulis bermaksud melakukan telaah kritis menggunakan paradigma ekonomi keberlanjutan islam terhadap UU No.11 tahun 2020 Cipta Kerja Klaster Lingkungan Hidup dengan tujuan menjelaskan aspek resiko bagi lingkungan dan melakukan pembaacaan bagaimana seharusnya konsep ekonomi berkelanjutan dalam Islam. Oleh sebab itu penulis akan menitik beratkan penilitian ini perihal Proyeksi Ekonomi Beberlanjutan Dalam UU Nomor 11 Tahun 2020 Dalam Prespektif Maslahat Sebagai Nilai Fundamental Ekonomi Islam.

\subsection{Rumusan Masalah}

Sebagai pijakan dan sekaligus juga sebagai pembatasan dalam pembahasan tulisan ini dikemukan rumusan masalah Bagaimana Proyeksi Ekonomi Berkelanjutan dalam UU No.11 Tahun 2020 dalam Prespektif Maslahat Sebagai Nilai Fundamental Ekonomi Islam

\section{Metode Penelitian}

Penelitian tentang UU No.11 tahun 2020 tentang Cipta Lapangan Kerja Cluster Lingkungan Hidup Dalam Prespektif Ekonomi Keberlanjutan Islam ini merupakan penelitian yuridis normatif, yakni penelitian yang fokus terhadap telaah dari bahan hukum berupa undang-undang tertentu. Dalam kaitanya dengan penelitian ini, penulis menggunakan pendekatan undang-undang (statue Approach) yang mana akan ditelaah berbagai aturan yang berkaitan dengan permasalahan hukum lingkungan. Dan kemudian mengkombinasikan dengan pendekatan perbandingan yang mana dalam hal ini penulis menggunakan hukum islam sebagai pembanding dan instrumen dalam menentukan preskripsi penelitian.

\section{Hasil dan Pembahasan}

\subsection{Proyeksi Ekonomi Beberlanjutan Dalam UU Nomor 11 Tahun 2020 Dalam} Prespektif Maslahat Sebagai Nilai Fundamental Ekonomi Islam.

\section{A. Hifdz biah sebagai maqashid syariah}

Dalam ayat al-quran maupun hadist ditemukan banyak sekali literatur yan menunjukan bahwa allah swt dalam penciptaan alam tidaklah ada yang sia-sia. Setiap penciptaan alam beserta isinya mempunyai maksud tertentu, hal tersebut secara implisit tertuang dalam firman Allah SWT berikut :

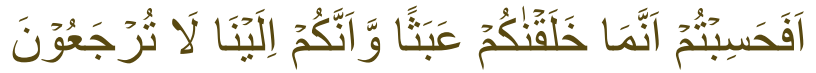

Artinya "Maka apakah kamu mengira, bahwa Kami menciptakan kamu main-main (tanpa ada maksud) dan bahwa kamu tidak akan dikembalikan kepada Kami?" (QS. al-Mukminun : 115)

Dalam penciptaan ini Allah SWT juga sekaligus menurunkan instrumen pengaturannya yakni syariah yang sampaikan oleh nabi muhammad saw. Adapun maksud didatangkanya syariah tersebut semata-mata untuk kemaslahatan mahluk atau dalam konteks ini kemaslahatan unuk manusia. Menurut imam asy-syathibi, substansi dari syariat sendiri dapat digali melalui pedoman eksternal syariah tanpa meninggalkan 
hikmah yang tersembunyi ataupun sebaliknya. Penggalian makna tersebut diambil dari hikmah yang terkandung dibalik penetapan syari'ah tanpa mempertentangkan dengan isi tekstual nash tersebut. Hal inilah yang menjadi pedoman ulama' dalam menentukan substansi dari penetapan syaria' at. ${ }^{13}$

Imam ghazali dalam kitab Al-Mustashfa berpendapat "Maslahat ialah menjaga tujuan-tujuan syariat, bukan sebuah istilah untuk meraib kemanfaatan dan menghindari resiko kerusakan, karena meraih kemanfaatan dan menghindari keburukan merupakan tujuan dan kepentingan makhluk. Tujuan syariat demi kepentingan makhluk itu ada lima yaitu menjaga agama, nyawa, akal, keturunan, dan harta. Setiap tindakan yang memiliki muatan penjagaan terhadap lima prinsip dasar ini, maka itulah maslahat. Dan setiap tindakan yang merusak lima prinsip dasar ini, maka itulah mafsadat, sedangkan menjaganya berarti maslahat (pula)"14. Dapat kita pahami bahwa maksud imam ghazali dalam pemaknaan maqashid syariah menegaskan bahwa penjagaan atas 5 parameter maslahat diatas tidak akan berlawanan dengan maqashid syariah.

Dalam kaitanya dengan penjagaan atas jiwa (hifdz nafs) dalam upaya mewujudkannya erat kaitanya dengan pelestarian lingkungan. hal tersebut dikarenakan untuk mewujudkan eksistensi manusia dibutuhkan daya dukung lingkungan yang memadai seperti lahan untuk pangan, pelestarian hutan untuk suplai oksigen, perlindungan sumber air untuk kehidupan dan banyak yang lainya. Ali Yafi berpendapat bahwa hifdz nafs menempati urutan pertama dalam skala prioritas kehidupan manusia, sehingga menjaganya merupakan kewajiban utama15. Sebaliknya, perusakan atas lingkungan dapat diartikan perusakan atas penjagaan jiwa manusia yang berdampak pada kehidupan sekarang dan juga masa mendatang.

Selain hifdz nafs, penjagaan atas harta benda juga menempati peran yang vital dalam kaitanya dengan kelestarian lingkungan. segala sesuatu yang mendukung daya hidup atau eksistensi manusia merupakan harta dalam artian luas. Sebagai contoh hutan yang menyediakan seluruh kebutuhan manusia dengan hasil produksinya serta tanah yang dari sanalah sumber kehidupan air dan pangan merupakan harta yang tak terhingga nilainya. Begitu juga dengan hifdz nasl, ketika alam rusak maka keberlangsungan kehidupan manusia juga akan terancam.

Dari uraian diatas dapat kita tarik kesimpulan bahwa penjagaan atas alam merupakan suatu kewajiban yang mutlak yang mana interkoneksi dari konsekuensi rusaknya alam berdampak pada seluruh aspek-aspek penjagaan dalam maqashid syariah. Hal tersebut diuraikan dalam QS. Al-A'raf : 56
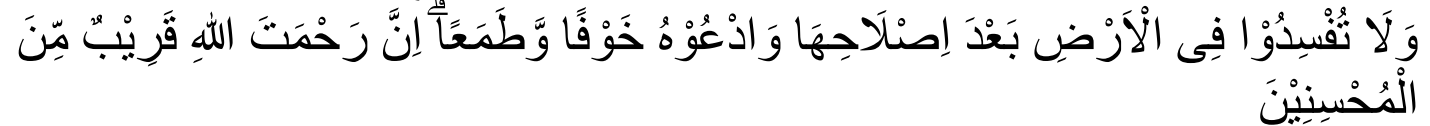

Artinya "Dan janganlah kamu berbuat kerusakan di bumi setelah (diciptakan) dengan baik. Berdoalah kepada-Nya dengan rasa takut dan penuh harap. Sesungguhnya rahmat Allah sangat dekat kepada orang yang berbuat kebaikan"

\section{B. Tinjauan Atas Instrumen Perlindungan Dan Pelertarian Dalam UU Cipta Kerja}

\footnotetext{
${ }^{13}$ As-Syatibi, al-Muwafagat, Vol II, (Cet. Maktabah as-Syamilah), h. 391-393

14 Al-Ghazali, al-Mustarshfa fi Ilm al-Usbil. (1993), Cet.I (Beirut: Dar al-Kutub al Ilmiyah, hlm. 174.

${ }^{15}$ Ali Yafi, Merintis fiqib lingkungan hidup, (2006), cet. 1, Jakarta, Ufuk Press, hlm. 163-185.
} 
Dalam pengaturan tentang penjagaan atas alam ini, salah satu subjek yang representatif dalam membat aturan, menjalankan aturan dan melakukan penindakan apabila ada pelanggaran adalah negara (Waliyyul Amr) yang mana hal tersebut sesuai dengan kaidah fiqhiyyah sebagai perwakilan kepentingan ummat. Hal tersebut sesuai dengan hukum yang tekandung dalam hadist nabi muhammad saw ${ }^{16}$ :

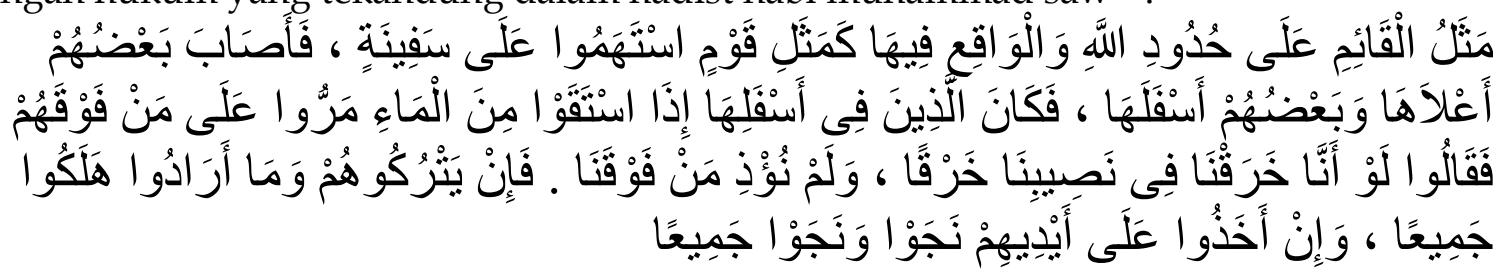

Artinya "Perumpamaan orang yang mengingkari kemungkaran dan orang yang terjerumus dalam kemungkaran adalah bagaikan suatu kaum yang berundi dalam sebuah kapal. Nantinya ada sebagian berada di bagian atas dan sebagiannya lagi di bagian bawah kapal tersebut. Yang berada di bagian bawah kala ingin mengambil air, tentu ia harus melewati orang-orang di atasnya. Mereka berkata, "Andaikata kita membuat lubang saja sehingga tidak mengganggu orang yang berada di atas kita." Seandainya yang berada di bagian atas membiarkan orang-orang bawah menuruti kehendaknya, niscaya semuanya akan binasa. Namun, jika orang bagian atas melarang orang bagian bawah berbuat demikian, niscaya mereka selamat dan selamat pula semua penumpang kapal itu." (HR. Bukhari no. 2493).

Sebagai representasi dari kepentingan ummat, negara dituntut untuk membuat regulasi perlindungan dan pelestarian lingkungan yang berorientasi pada kemaslahatan umat, hal tersebut mengacu pada salah satu kaidah fiqih :

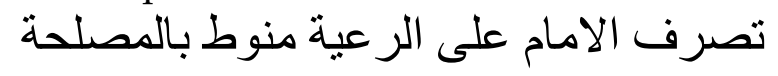

Artinya: "Kebijakan imam/pemerintah bagi rakyat harus berdasar maslahah,"

Berikut adalah pandangan islam terhadap aturan-aturan yang menjadi garda depan pelestarian dan penjagaan lingkungan dalam hal ini adalah UU No. 11 tahun 2020 tentang cipta kerja:

\section{Tahap Perencanaan}

Telah diuraikan di atas dalam tahap perencanaan regulasi yang diatur dalam perubahan UU PPLH maupun UU tata ruang memiliki banyak kekurangan. Pelemahan instrumen perlindungan hidup nampak nyata sejak dalam tahap perencanaan perubahan UU No. 26 Tahun 2007 tentang Penataan Ruang dalam UU Cipta Kerja merubah aturan sebelumnya yang mana dalam perubahan tersebut beberapa proyek strategis nasional diperbolehkan dibuka tanpa melewati prosedur rencana tata ruang wilayah.

Perubahan selanjutnya pada peninjauan kembali RTRW wilayah, yang mana dengan dalih proyek strategis nasional pemerintah memperbolehkan peninjauan rtrw lebih dari sekali dalam lima tahun. Selain itu, perlu dipahami bahwa kajian penataan ruang merupakan bentuk RTRW yang disesuaikan dengan pembangunan ekonomi, sosial dan lingkungan. Namun demikian, tinjauan semacam ini pun harus dibatasi oleh asas kepastian hukum, sehingga tidak dapat ditinjau kembali dengan alasan yang terlalu kabur. Tidak terdefinisikan dengan jelasnya "kebijakan strategis nasional" justru

${ }^{16}$ Lihat Shahih Bukhari, hadis nomor 2493. 
menunjukkan bahwa penataan ruang tidak menerapkan prinsip kepastian hukum secara ketat, dan membuka ruang yang luas bagi pemerintah untuk mengubah tata ruang secara nonprosedural.

Begitu juga dengan dokumen amdal, dokumen yang nantinya akan digunakan sebagai prasyarat kegiatan usaha yang berpotensi besar terjadi kerusakan lingkungan. dalam perubahan regulasi ini,dokumen analisis mengenai dampak lingkungan juga mengalami reduksi besar-besaran. Dalam uu cipta kerja partisipan penyusun dokumen amdal dibatasi hanya masyarakat terkena dampak langsung, serta tim penilai amdal diganti dengan tim uji kelayakan yang dalam keanggotaannya tim uji kelayakan ini terkesan inklusif, selain itu akses informasi publik terkait pemntauan serta pengawalan dokumen amdal juga dikurangi.Dari beberapa catatan diatas tentu tidak sesuai dengan kaidah fiqh

Artinya " kemudharatan harus dihilangkan semampunya",

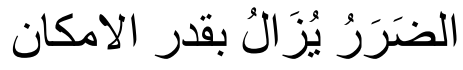

Yang mana beberapa regulasi tersebut harusnya dapat dimaksimalkan sebagai instrumen pencegahan perusakan lingkungan yang menyebabkan kemudharatan semaksimal mungkin tepatnya tingkat awal yakni sejak dalam perencanaan.

\section{Regulasi Keterlanjuran}

UU No. 18 Tahun 2013 Sebagaimana diubah dalam UU Cipta Kerja mengatur mekanisme tentang peyelesaian keterlanjuran kegiatan kawasan hutan yang tidak mengantongi izin dibidang kehutanan maupun kegiatan usaha. Aturan tersebut tertuang dalam Pasal 110A untuk kegiatan yang memiliki izin usaha tetapi tidak memiliki izin di bidang kehutanan) dan Pasal 110B (tidak memiliki izin usaha dan tidak memiliki izin bidang kehutanan. Sebelumnya, ketentuan penyelesaian keterlanjuran diatur dalam Pasal 51 PP Nomor 104 Tahun 2015 tentang Tata Cara Perubahan Peruntukan dan Fungsi Kawasan Hutan (PP No. 104 Tahun 2015) dengan regulasi cukup tegas memuat batasan yang tegas perihal penyelesaian keterlanjuran maksimal 1 tahun sejak berlakunya PP.

Dalam perubahan pada uu cipta kerja, regulasi ini cukup dilonggarkan dengan memperpanjang waktu penyelesaianya. Pelonggaran ini mengingatkan kita pada wacana forest amnesty (amnesti bagi keterlanjuran penggunaan dan pemenfaatan kawasan hutan). Forest amnesty beorientasi untuk meningkatkan pendapatan nasional dan pertumbuhan ekonomi, serta meningkatkan kesadaran dan kepatuhan masyarakat dalam memenuhi kewajiban perpajakan dan kewajiban lainnya (termasuk restorasi hutan). Besarnya konsensi dan tingginya peran perkebunan kelapa sawit terhadap pertumbuhan ekonomi dianggap menjadi alasan kuat untuk diwujudkanya aturan ini.

Regulasi ini mengabaikan posisi hutan sebagai sumber kehidupan, yang mana dalam forest amnesty hutan seolah hanya dipandang sebagai nilai pertukaran yang menghasilkan nilai lebih dari hasil buminya serta dalam kompensasi para pelaku usahanya yang mana harusnya sisi eksternalitas mutlak harus diperhatikan dalam penyusunan aturan ini.

Allah berfirman dalam surat Ar-Rum ayat 41 yang berbunyi ;

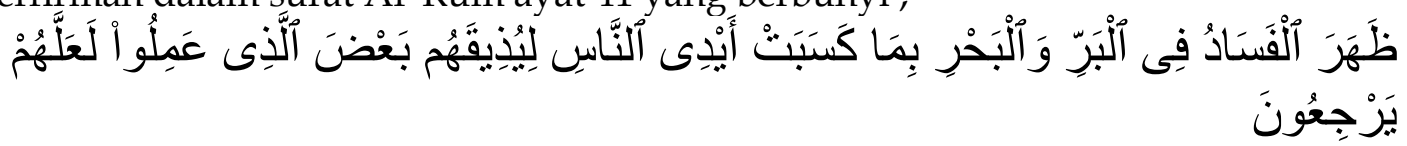


Artinya: "Telah nampak kerusakan di darat dan di laut disebabkan karena perbuatan tangan manusia, supaya Allah merasakan kepada mereka sebahagian dari (akibat) perbuatan mereka, agar mereka kembali (ke jalan yang benar)" (Q.S. Ar Rum:41)

Dalam firman Allah SWT tersebut menjelaskan bahwa perusakan-perusakan alam itu disebabkan oleh tangan manusia. Dalam hal ini pelonggaran regulasi terhadap kegiatan-kegiatan usaha tak berizin juga termasuk didalamnya. Dengan orientasi penerimaan pendapatan negara dari kompensasi keterlambatan disatu sisi yang selanjutnya mengabaikan eksternalitas seperti penggundulan hutan (deforestsiasi), rusaknya keanekaragaman hayati tentu berpotensi menimbulkan bencana yang mengakibatkan kerugian lebih besar lagi. Maka hal tersebut jelas berlawanan dengan qowaidh fiqhiyyah

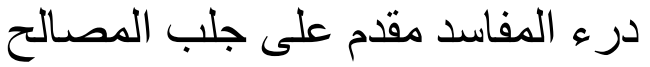
Artinya:"Menolak kerusakan lebih diutamakan dari pada mengharapkan kemaslahatan" yang mana apabila hadapkan antara pundi-pundi devisa dalam penerimaan negara yang dipandang maslahat dengan kerusakan yang diakibatkan dari deforestiasi tentu penolakan akan kemudharatan harus didahulukan. Mengingat kerusakan hutan tentu akan mengganggu metabolisme alam yang pada ahirnya akan mengganggu penjagaan atas jiwa manusia (hifdz nafs) dan keberlanjutan untuk anak cucu kita dimasa depan (hifdz nasl).

\section{Sangsi Administratif}

Dalam Islam, sangsi dikenal dengan Jarimah ta'zir adalah hukuman yang sanksinya ditentukan oleh pemerintah ${ }^{17}$. Oleh karena itu, menurut syariat Islam, apabila perbuatan manusia yang diduga menimbulkan bencana seperti pembalakan liar dan pengeboran minyak/gas ditengarai secara serius atas kelalaian atau penggunaan yang melampaui batas kewajaran, maka pihak tersebut berkewajiban untuk mengganti kerugian tersebut (fauqal adat) ${ }^{18}$. Sedangkan sangsinya adalah ta'zir sesuai perundang-undangan dan mengganti semua kerusakan, baik berupa materi maupun non materi ${ }^{19}$

Dalam konteks indonesia perundang-undangan terbaru tentang perlindungan lingkungan hidup terdapa pada UU Cipta Kerja. UU ini merubah, menambahkan serta menghapus sejumlah aturan, salah satunya adalah Undang-Undang Nomor 32 Tahun 2009 tentang Undang-Undang Perlindungan dan Pengelolaan Lingkungan Hidup. Regulasi perihal sangsi merupakan aturan yang mengalami perubahan signifikan dalam hal ini termasuk sanksi administrasi yang mana didalamnya ditambahkan nomenklatur denda administratif.

Jenis denda administrasi ini disebut denda karena keterlambatan yang dikenakan oleh pemerintah. Pada sisi lain, dalam naskah akademis UU Cipta Kerja menunjukkan bahwa UU ini secara konseptual beorientasi mengutamakan penerapan sanksi

${ }^{17}$ Muhyi ad-Din Abi Zakaria bin Syarf an-Nawawi, Minhaj at-Thalibin wa Umdah al-Muftin, (Cet. 4; Beirut Beirut Dar Al-kunub Al-Ilmiyah, 2012M/1433H), hlm. 303

${ }^{18}$ Abd Al-Rahman bin Muhammad Ba'alawi, Bugbyah Al-Mustarsyidin, (Cet. 4; Beirut Beirut Dar Alkunub Al-Ilmiyah, 2012M/1433H), hlm. 177.

${ }^{19}$ Sihab al-Din Ibn Hajr al-Haitami, Tuhfâtul Muhtâj Fi Hawasyi Syarwani, Voi VIII (Cet. 3; Beirut, Dar Al-kutub Al-Ilmiyah, 2012M/1433H), h. 15-18 
administrative yang selanjutnya sangsi pidana untuk perbuatan tertentu. Sayangnya, UU Cipta Kerja tidak mengatur secara spesifik bagaimana menggunakan atau mengoptimalkan sanksi administratif lingkungan untuk mencapai kepatuhan tersebut.

Pelaksanaan forest amnesti seperti yang telah dijelaskan diatas pada dasarnya merupakan solusi dengan hanya membayar sanksi administrasi berupa denda kemudian membayar $\mathrm{PSDH}$ dan $\mathrm{DR}^{20}$. Hal tersebut memicu kontroversi mengingat menurut peraturan sebelumnya, pelanggaran terhadap kelanjuran operasi atau kegiatan di kawasan hutan tersebut memungkinkan untuk dikenai sangsi pidana. Namun, UU Cipta Kerja memberikan kelonggaran untuk menyelesaikan masalah hanya melalui sanksi administratif. Kemudian akan timbul kesan bahwa pembuat kebijakan tidak mau memberikan sanksi kepada pelanggar, karena bentuk sangsi yang dikenakan diatas dalam aturan sebelumnya merupakan kewajiban. Hal ini memicu kemungkinan bahwa pelaku akan dibebaskan dari tanggung jawab hukum dan mengulangi kesalahan yang sama.

Peraturan turunan dari UU Cipta Kerja, PP No. 24 Tahun 2021 juga menjelaskan bahwa paksaan pemerintah merupakan sanksi administratif yang memberikan efek yang dapat dipaksakan, termasuk pemblokiran, pencegahan devisa, penyitaan aset, dan/atau pemaksaan membayar denda administrasi. Padahal, jika dilihat dari fungsinya paksaan pemerintah merupakan jenis sangsi restoratif yang bertujuan memulihkan lingkungan dengan cepat. Tindakan pemaksaan pemerintah dalam PP No. 24 Tahun 2021 sebenarnya tidak berperan dalam pemulihan lingkungan, tetapi hanya tampak sebagai hukuman yang bersifat punitif.

Kesimpulan dari uraian diatas bahwasanya ta'zir yang diterapkan dalam hal ini lebih condong mengedepankan sangsi administratif dengan pendekatan amnesty (bil'mal). Dalam kacamata ekonomi kapitalistik mungkin ta'zir semacam ini merupakan salah satu maslahat mengingat orientasi utamanya adalah penambahan akumulasi atau dalam hal ini mengejar pertumbuhan ekonomi. Namun dalam konteks lingkungan alih-alih memperoleh maslahat dengan mengejar pertumbuhan ekonomi salah satunya lewat sangsi administratif, yang terjadi malah akan membuat pelanggaran-pelanggaran tak memiliki efek jera dalam pelanggaranya serta.

Efek domino dari rangkaian mekanisme sangsi tersebut akan menyuburkan kerusakan-kerusakan lingkungan di Indonesia. Yang mana hal tersebut jelas bertentangan dengan firman Allah SWT :
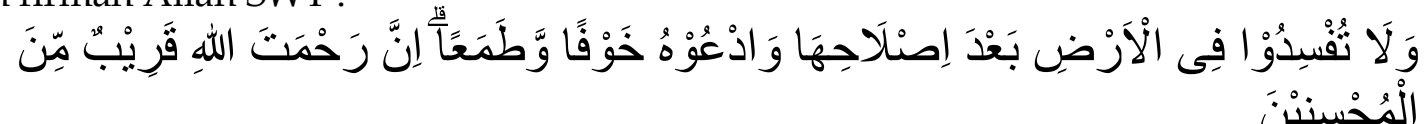

Artinya "Dan janganlah kamu berbuat kerusakan di bumi setelah (diciptakan) dengan baik. Berdoalah kepada-Nya dengan rasa takut dan penuh harap. Sesungguhnya rahmat Allah sangat dekat kepada orang yang berbuat kebaikan." .(Q.S al-'Araaf:56).

\section{Kesimpulan}

${ }^{20}$ PP No. 24 tahun 2021 Tentang Tata Cara Pengenaan Sangsi Administratif Dan Tata Cara Penerimaan Bukan Pajak Yang Berasal Dari Denda Administratif Atas Usaha Yang Telah Dibangun Dalam Kawasan, bagian penjelasan umum, pasal 8 ayat (3). 
Secara ringkas Kesimpulan Hasil Penelitian ini ialah di mulai sari tahap perencanaan tata ruang dan penyusunan dokumen AMDAL cenderung melemahkan peran masyarakat serta pengurangan hak akses informasi masyarakat terkait lingkungan dan ekonomi Sedangkan dalam pandangan maqashid syariah yang dalam hal ini merupakan framework ekonomi berkelanjutan islam, penetapan regulasi dalam UU No 11 tahun 2020 masih membutuhkan perbaikan dalam banyak sisi. Hal itu dikarenan dari beberapa regulasi perlindungan dan pelestarian lingkungan sebagai instrumen hifdz bi'ah masih bertentangan dengan lima dasar tujuan syari'ah yang harus dilindungi dan di rawat diantaranya: (1) Hifdz al-din, (2) Hifdz al-nafs, (3) Hifdz al-'aql, (4) Hifdz al-nasl, dan (5) Hifdz al-mal. Kondisi pandemi yang mengakibatkan lesunya perekonomian nasional menjadi dalih pemerintah untuk membuat regulasi yang bertujuan untuk mepercepat investasi. Namun patut menjadi catatan memprioritaskan ekonomi tanpa memperhatikan kondisi lingkungan dan sosial masyarakat tentu akan memberikan dampak negatif bagi keberlanjutan lingkungan hidup. Rusaknya lingkungan hidup sebagai pendukung esensial kehidupan manusia akan berakibat terancamnya kehidupan/eksistensi manusia itu sendiri.

\section{Daftar Pustaka}

\section{A. Buku}

Abdullah, Boedi (2004), Peradaban Pemikiran Ekonomi Islam, Bandung: Pustaka Setia.

Abdullah, M. Amin (2004), Neo Ushul Figh Menuju Ijtihad Kontemporer; Paradigma Alternatif Pengembangan Ushul Figh Dan Dampaknya Pada Fiqh Kontemporer. ed. Riyanta. Yogyakarta: Fakultas Syariah UIN Sunan Kalijaga.

Afif Abd Fattah Tabbara (1986). Dosa Dalam Pandangan Islam, terjemahan oleh Bahrun Abu Bakar, Cetakan III Bandung: Risalah.

Ahmad Musthafa Al Maraghi (1987). Terjemah Tafsir Al-Maraghi. Semarang: PT Karya Toha Putra.

Ahmad Redi dan Ibnu Sina Chandranegara, (2020), Omnibus Law: Diskursus Pengadopsiannya ke dalam Sistem Perundang-Undangan Nasional , Depok: RajaGrafindo Persada.

Al-Qardawi, Yusuf (2006), Figh Maqashid Syari 'ah. Jakarta: Pustaka AlKautsar.

Audah, Jaser (2013). Al-Maqashid Untuk Pemula. Yogyakarta: UIN Sunan Kalijaga Yogyakarta Press.

Audah, Jaser (2013). Al-Maqashid Untuk Pemula. Yogyakarta: UIN Sunan Kalijaga Yogyakarta Press.

Chapra M Umar (2000). Sistem Moneter Islam, terjemahan oleh Ikhwan Abidin. Jakarta:

Gema Insani Press.

Chapra, M Umar (2000), Islam Dan Tantangan Ekonomi. Jakarta: Tazkia Institute . Eriyanto (2011). Analisis Isi: Pengantar Metodologi Untuk Penelitian Ilmu Komunikasi dan Ilmu-Ilmu Lainnya . Cetakan I, Jakarta: Prenamedia Group. 
Fred magdof and Foster (2011), Lingkungan hidup Dan Kapitalisme, Terjemahan oleh Pius Ginting, Cetakan I. Tanggerang Selatan:Marjin Kiri.

Ghofur, Abdul (2017), Pengantar Ekonomi Islam. Jakarta: Raja Grafindo Persada.

Hadari Nawawi (1995), Metode Penelitian Bidang Sosial. Yogyakarta: Gajah Mada University Press.

Jhon Bellamy Foster (2010) et.al., The Ecological Rift . New York: Montly Review Press.

James Midgley (2005.), Pembengunan Sosial: Persepektif Pembangunan dalam Kesejahteraan Sosial. Jakarta: Ditperta Islam Depag RI.

Jimly Asshiddiqie (2020) . Omnibus Law dan Penerapannya di Indonesia. Jakarta: Konstitusi Press.

M.Quraish Shibab (2012). Tafsir Al-Misbah Vol 1. Jakarta, Lentera Hati.

Mufid, Mohammad (2016). Ushul Figh Ekonomi Dan Keuangan Kontemporer Dari Teori Ke Aplikasi. Jakarta: Kencana Prenada Media.

Peter Mahmud Marzuki (2005), Penelitian Hukum. Jakarta:Kencana.

Praja, Juhaya S (2015). Ekonomi Syariah. Bandung: Pustaka Setia

Sabian Utsman (2014). Metodologi Penelitian Hukum Progresif. Yogyakarta:Pustaka Pelajar.

Sahrawardi K. Lubis (2000). Hukum Ekonomi Islam. Jakarta: Sinar Grafika.

Sayyid Quthb (1984). Keadilan Sosial Dalam Islam, terjemahan oleh Afif Mohammad,. Bandung: Pustaka.

Soejono Soekanto dan Sri Mamudji (2014). Penelitian Hukum Normatif Suatu Tinjauan

Singkat. Jakarta: PT RajaGrafindo Persada.

Soerjono Soekanto(2014). Pengantar Penelitian Hukum. Jakarta:Universitas Indonesia.

Wan Mohammad Nor Wan Daud (2011), Budaya Ilmu dan Gagasan 1 Malaysia; Membina

Negara Maju dan Bahagia. Kuala Lumpur: CASIS UTM International Campus

\section{B. Peraturan Peundang-undangan}

Undang-undang Nomor 12 Tahun 2011 tentang Pembentukan Peraturan Perundangundangan (25 juni 2021). https://bphn.go.id/data/documents/11uu012.pdf

UU No.32 tentang Perlindungan Dan Pengelolaan Lingkungan Hidup 25 juni 2021). https://jdih.esdm.go.id/storage/document/UU\%2032\%20Tahun\%202009\%20(P PLH).pdf

\section{Artikel Jurnal}

Putra, Antoni. (Februari, 2020) "Penerapan Omnibus Law Dalam Upaya Reformasi Regulasi" Jurnal Legislasi Indonesia,17.

Nasitotul Janah, Abdul Ghofur, (2018)."Maqashid As-Ayari'ah sebagai Dasar 
Pengembangan Ekonomi Islam”, International Journal Ihya' 'Ulum Al-Din, 20.

Helmi Fitria, Retno Kusniati. (Januari 2021)." Penggunaan Omnibus Law Dalam Reformasi Regulasi Bidang Lingkungan Hidup Di Indonesia", Jurnal Masalah-Masalah Hukum, Jilid 50

Khaerul Aqbar, Azwar Iskandar. (2020). "Konsep Al-Falah Dalam Islam Dan Implementasinya Dalam Ekonomi", Bustanul Fuqaha: Jurnal Bidang Hukum Islam,1.

Nila Amalia," Problematika UU Cipta Kerja Sektor Lingkungan Hidup" Jurnal Syariati vol.VI No.2, (November 2020) hal.2.

Rockström J, Steffen W, Noone K, Persson A, Chapin FS 3rd, Lambin EF, Lenton TM, Scheffer M, Folke C, Schellnhuber HJ, Nykvist B, de Wit CA, Hughes T, van der Leeuw S, Rodhe H, Sörlin S, Snyder PK, Costanza R, Svedin U, Falkenmark M, Karlberg L, Corell RW, Fabry VJ, Hansen J, Walker B, Liverman D, Richardson K, Crutzen P, Foley JA. A safe operating space for humanity. Nature. 2009 Sep 24;461(7263):472-5. doi: 10.1038/461472a. PMID: 19779433.

Sentot Sudarwanto dan Dona Budi Kharisma. (April, 2020)" Omnibus Law Dan Izin Lingkungan Dalam Konteks Pembangunan Berkelanjutan". jurnal RechtVinding, 9.

Sofi Mubarok dan Muhammad Afriza. (Januari 2018)." Islam Dan Sustainable Development: Studi Kasus Menjaga Lingkungan dan Ekonomi Berkeadilan". Jurnal Daulliyah, 3.

Suwandi Arham. (Oktober 2019) . “Omnibus Law Dalam Perspektif Hukum Indonesia". Jurnal Petitum, 7.

\section{Website Resmi}

Agustiyanti (09 juni 2021). “Jokowi Sebut 42 Ribu Aturan Hambat RI Ikuti Perubahan Global",CNNIndonesia, https:/ / www.cnnindonesia.com/ekonomi/20171024125609-92-250596/jokowisebut-42-ribuaturan-hambat-ri-ikuti-perubahan-global, Selasa, 24/10/2017.

Syaikh Muhammad Muhyiddin Qaradaghi (24 mei 2021) "al Falah fi al Kitab wa as Sunnah".

http://www.qaradaghi.com/portal/index.php?option=com_content\&view=artic le\&id=2337:-1- 4\&catid=9:2009-04-11-15-09-29\&Itemid=7

Viva Budy Kusnandar (24 September 2019)." Berapa Jumlah Penduduk Muslim Indonesia?". https://databoks.katadata.co.id/datapublish/2019/09/24/berapajumlah-penduduk-muslim-indonesia 